УДК 621.396

\title{
НЕОБХОДИМОСТЬ И ВОЗМОЖНОСТЬ УЧЕТА ПРОСТРАНСТВЕННО-ВРЕМЕННЫХ ПАРАМЕТРОВ МЕШАЮЩИХ ОТРАЖЕНИЙ ОТ ПОДСТИЛАЮЩЕЙ ПОВЕРХНОСТИ ПРИ ПОСТРОЕНИИ ПОМЕХОЗАЩИЩЕННЫХ САМОЛЕТНЫХ РЛС ОБЗОРА ВОЗДУШНОГО ПРОСТРАНСТВА
}

\author{
ГАРТОВАНОВ В. Г., БАТЫЕВ В. Д.
}

Харьковский университет Воздушных Сил, Украина, Харьков, 61023, ул. Сумская 77/79

\begin{abstract}
Аннотация. Построение помехозащищенных РЛС невозможно без знания параметров помех. Основная трудность построения помехозащищенных самолетных РЛС обзора воздушного пространства связана с подавлением отражений от подстилающей поверхности. Для оценки азимутально-скоростных параметров этих отражений в самолетных РЛС обзора воздушного пространства с однозначным измерением дальности использована имитационная модель реализаций на цифровом выходе когерентного радиолокационного приемника. При создании модели использованы цифровые карты местности и антенна с малым уровнем боковых лепестков. Путем моделирования обоснована необходимость и возможность построения помехозащищенных самолетных РЛС при малоканальном построении и одновременном использовании прямых межпериодных и межканальных корреляционных связей
\end{abstract}

Ключевые слова: самолетная РЛС; помехозащита; отражение от подстилающей поверхности; азимутально-частотная характеристика

\section{ВВЕДЕНИЕ}

Проблема всеракурсного обнаружения малоскоростных маловысотных малоразмерных воздушных объектов активными самолетными РЛС обзорного типа не нашла достаточной теоретической и экспериментальной проработки. Трудности решения этой проблемы связаны с комбинированным воздействием на РЛС мешающих отражений от подстилающей поверхности и различных внешних электромагнитных излучений. Применение в самолетных РЛС высокой и средней частот повторения зондирующих сигналов усложняет решение этой проблемы в радиолокационном смысле. Подробный обзор различных самолетных радиолокационных систем дальнего обнаружения воздушных объектов приведен в [1]. Ни

DOI: $10.20535 / \mathrm{S} 0021347016060042$

(С) Гартованов В. Г., Батыев В. Д., 2016 в одной из этих систем проблема всеракурсного радиолокационного обнаружения воздушных объектов не решена.

Потенциальные возможности решения названной проблемы имеются в системе «Хокай», что делается в рамках ее модернизации. Однако возможности обнаружения этой системы при полете над густозаселенными и промышленными районами далеки от потенциальных.

В данной статье путем имитационного моделирования с использованием цифровых карт местности показано возможное направление решения этой проблемы применительно к самолетным РЛС с однозначным измерением дальности. Следует отметить особую роль в 